\title{
ATRIA, Fernando. Derechos Sociales y educación: un nuevo paradigma de lo público. Santiago: Lom ediciones, 2014.
}

\section{Por Marina Feldman}

O último livro de Fernando Atria é uma obra cheia de proposições ambiciosas e inter- relacionadas, ainda que com um olhar pragmático que mantém preso ao solo de onde escreve ${ }^{1}$. Algumas delas dizem respeito diretamente a modificar o sistema educacional chileno. Outras, tratam sobre como superar o paradigma neoliberal. Mas, a mais geral e interessante delas é a que o vincula a uma esquerda que se reconhece no passado e busca reinvenção para mirar o futuro. Trata-se da proposição de resgatar o sentido político e a centralidade da palavra socialismo. O autor questiona seus leitores logo de início se a figura de Allende os interpela, os implica e dá sua própria resposta. Ao enxergar um caminho de esquerda pela via da institucionalidade, em uma pedagogia lenta, que não vê o socialismo como telos estático, mas como direção de movimento, Atria se mostra implicado por essa herança².

Para trilhar esse caminho, dialoga em toda a obra com a ideia de direitos sociais e a concepção de cidadania sob a qual estes direitos repousam. Para ele, isso implica falar em um caminho de mudança de paradigmas. Não tem receios de afirmar que o caminho que aponta é o correto e o faz com base em sua concepção de público: dizer que "cada um tem a sua verdade" é, para Atria, a "privatização final" (2014, p. 121). Privatização em que aqueles que possuem o poder, a influência e a expertise, afirmam que têm a "sua verdade", negandose a colocá-la em discussão com "outras verdades" e afirmando o status quo de um modo que naturaliza seu autoritarismo. O que ele se propõe a fazer é distinto e requer clareza. O próprio intuito de escrever um livro é, para Atria, apresentar ao leitor motivos pelos quais o que se está propondo é correto. Trata-se, para ele, de uma relação simétrica em que seu desejo é convencer o leitor da correção de suas ideias e em que o leitor pode desejar convencê-lo do contrário, necessitando apenas reunir argumentos e colocá-los em discussão.

Mas de que, afinal, Atria está tentando nos convencer? A resposta dessa pergunta precisa ser feita em partes. Como questão de fundo está, como já apontamos, a ideia de que um caminho diferente é possível, que podemos criar formas de sociedade mais humanas e menos predatórias. Depois disso, temos a ideia de que os direitos sociais diferem, sim, dos direitos individuais, mas não pelos motivos usualmente apresentados, e sim porque em sua essência remontar a um paradigma diferente de cidadania. Mais além, a partir da metáfora dos direitos sociais como enxertos na sociedade liberal, quer nos demonstrar a possibilidade desse corpo intruso modificar seu receptor, em um processo de pedagogia lenta. Em seguida, elege a problemática da gratuidade da

1 Atria dialoga com o contexto chileno do chamado governo de "Concertación", que remete à coalizão político-partidária que surge originalmente como oposição ao regime ditatorial de Pinochet e que se mantém no poder entre os anos de 1990 e 2010 . Atria considera que as obras deste governo consistiram em humanizar a herança da ditadura, mesmo porque atuaram no mesmo marco legal, da Constituição de 1980, e porque almejavam primeiramente a manutencão da normalidade institucional. Reconhecida necessidade desse papel, Atria volta sua crítica ao sistema educacional chileno de "quasemercado", baseado em subvenções, que foi instituído ao longo destes governos. Cabe lembrar, também, que Atria escreve já no contexto do governo Bachelet, eleita pelo Partido Socialista do Chile e que, em sua campanha, se comprometeu a modificar o sistema vigente, retomando princípios de gratuidade universal.

2 Fernando Atria é professor de direito na Universidad de Chile e na Univesidad Adolgo Ibáñez, sendo participante ativo do presente debate sobre as reformas educacional e constitucional no Chile e militante do Partido Socialista. 
educação para indicar uma via pela qual essa contaminação do paradigma neoliberal por um novo paradigma de direitos sociais é possível. Por último, seus esforços se voltam a nos convencer de uma forma que considera adequada, em termos mais operacionais e práticos, para solucionar especificamente o caso chileno.

Sua compreensão do caso chileno e as soluções que aponta são apresentadas na segunda, terceira e quarta partes do livro, especialmente a partir do capítulo VII, aonde propõe o que chama de uma mudança "antigatopardista"3. A quarta e última parte se dedica exclusivamente à noção de público no ensino universitário. Já a reflexão das duas partes anteriores circula entre os diferentes níveis de ensino, ainda que o autor enxergue que o caminho lento e gradual deva começar pela gratuidade do Ensino Superior (que considera mais fácil de alcançar) para então seguir para a Educação Básica (que considera mais importante). A ordem invertida que propõe estaria justamente vinculada a sua ideia de um aprendizado gradual da cidadania.

As soluções que apresenta para o caso chileno são interessantes e pode-se que dizer que também pragmáticas. O autor dialoga com a realidade chilena com lucidez e se preocupa sempre em refutar possíveis argumentos em oposição - ainda que sua seleção de argumentos contrários seja, por vezes, caricatural. Também se explica em relação as suas escolhas de caminhos, baseado na impossibilidade de mudanças mais extremas na conjuntura presente. Para decidirmos, porém, se nos encontramos entre os leitores que concordam ou entre os que discordam dele (e reúnem argumentos para refutá-lo), se faz necessário voltar nosso olhar para a conjuntura chilena, bem como para outros autores que apontam caminhos diversos dos de Atria. Pode tratarse de um desafio interessante, mas não nos ateremos a isso por ora.

A nós, que temos o olhar voltado para o contexto brasileiro, interessam mais suas compreensões mais amplas: do paradigma neoliberal com sua lógica de mercado; da separação do sistema educacional desta esfera e da proposição de um novo paradigma. Para isso, vale detalhar brevemente caminho que o autor traça nas primeiras partes do livro.

Compreender e delimitar o que são direitos sociais, diferenciando estes dos direitos individuais, é o que se propõe fazer no primeiro capítulo. Nesse ponto, começa a tecer sua crítica aos juristas que denomina de "progressistas" (ATRIA, 2014, p. 34). Atria considera que, na tentativa de dar legitimidade e força normativa aos direitos sociais, tenta-se apagar as diferenças existentes entre estes e os direitos individuais. Na concepção do autor isso apagaria a natureza política, vinculada a cidadania, que é parte da noção de direitos sociais. Desse modo, não seria possível inserir os direitos sociais na concepção de justiça que hoje vigora, pois os direitos sociais mostram os limites de uma teoria contratualista. Por isso compreende, já no segundo capítulo, os direitos sociais como enxerto na sociedade liberal. É até possível garanti-los, mas disso decorrem duas possibilidades: ou a natureza dos direitos será modificada, transformando-os em direitos individuais a um mínimo, ou a presença desse "corpo estranho" modificará aos poucos a estrutura da sociedade. Segue, assim, em sua crítica àqueles que, para garantir a exigibilidade judicial, subvertem a própria essência dos direitos sociais como componentes da cidadania, passando a demandar um mínimo.

Mas, certamente não é só com os "progressistas" que Atria dialoga e discorda. Também refuta, por outro lado, a ideia de que os direitos sociais, estando sujeitos a escassez, somente poderão ser garantidos quando os recursos estiverem disponíveis, dentro da "reserva do possível". É à noção de escassez que Atria ira dedicar seu terceiro capítulo, aonde demonstra que todos os direitos estão sujeitos, em maior ou menor grau, a situações de escassez que podem gerar privações - como no caso de uma situação de guerra, em que o direito de ir e vir fica limitado por certas contingências. Falar em direitos sociais seria, portanto, falar em um modo de administrar a escassez, pois "afirmar que algo é um direito social não implica sustentar que não seja escasso, senão que,

3 A ideia de mudança gatopardista remete à novela italiana II Gattopardo, do escritor Giuseppe Tomasi, traduzida em português como " 0 Leopardo". Gatopardismo vincula-se a um contexto em que se "muda tudo para que as coisas permaneçam iguais". Quando fala em uma mudança antigatopardista, Atria sustenta a possibilidade de mudar pouco, fazendo com que tudo seja diferente, que é como entende a mudança no sistema de ensino superior chileno que propõe. 
como aquilo que é escasso é parte do conteúdo da cidadania, sua distribuição deve ser igualitária entre todo os que tem direito" (ATRIA, 2014, p. 57) . Em síntese, está se falando em uma distribuição baseada em critérios de cidadania, e não de mercado, e é aí que começa a se inserir uma problemática central para o autor: o mercado, independente de qualquer intenção boa ou ruim, é caracterizado pela busca de ampliação da produção e segmentação da sua distribuição. Ou seja, distribuir um bem pela via do mercado traz necessariamente certo grau de desigualdade, o que implica em que, ao afirmar o caráter de direito social de algum aspecto da vida, se faz necessário separar essa esfera do mercado.

Já no quarto capítulo, o autor nos demonstra que os direitos sociais são um caminho para uma sociedade distinta, assim como um bem em si. É o que Atria chama de "bem interno" (2014, p. 76) que, sendo produzido pela sociedade, caracteriza ao mesmo tempo meio e fim de um caminho de cidadania, reconhecimento do outro e aprendizado político. Trata-se do capítulo com viés mais filosófico, em que se baseia na ideia de Taylor de "pedagogia lenta", para retomar uma ética da virtude. Ética tal que, ao contrário do que afirmam os defensores do liberalismo político e da democracia representativa, não é irreal se se for compreendida como movimento gradual, de aprendizado coletivo. Usa, nesse contexto, o exemplo dos países escandinavos, em que as condições institucionais desenvolveram gradualmente nos indivíduos a compreensão de que seus interesses eram comuns, impedindo retrocessos significativos nos direitos sociais, mesmo em períodos de recessão.

É, portanto, para as condições institucionais que irá se voltar na segunda parte do livro, que intermedeia as considerações mais abstratas para a primeira parte com as indicações mais específicas, relativas à realidade chilena, que trará nas partes finais da obra. No quinto capítulo elege, como já dito, a gratuidade como problemática chave que, segundo ele, seria o caminho para a mudança de um paradigma neoliberal para um paradigma de direitos sociais. Baseado nas ideias vinculadas à ciência de Kuhn, Atria afirma que paradigmas são teorias que estruturam nossa forma de analisar e compreender o mundo. Esses paradigmas apontam para os problemas que são relevantes e merecem esforços no sentido de sua resolução. Também é nesse marco que se desenvolvem as chaves de análise dos problemas e as chaves de correção para as soluções apresentadas. E, note-se, se o paradigma é essa força estruturante do modo de pensar, ele também classificará o que está posto como problemático ou não. Na metáfora do autor, dois olhares de dois paradigmas diferentes na mesma direção podem enxergar coisas completamente distintas. Pode ser, inclusive, que aonde um enxerga o problema o outro enxergue a solução.

Nesses termos, o autor identifica uma hegemonia do paradigma neoliberal, que não permitiria enxergar certos problemas e vicissitudes, pois nega o público e insere todas as necessidades em um campo de problemas privados, que devem ser resolvidos pelo indivíduo através do mercado. Ou, em sua versão "com rosto humano"5, o governo neoliberal garantiria acesso a determinados bens mínimos, apenas para aqueles que não puderam acessá-los pela via do mercado. Nesse contexto, porém, a problemática da qualidade dos serviços ofertados pelo estado diz respeito apenas àqueles que, sendo desfavorecidos, tem menos poder e influência para garantir uma oferta de qualidade.

Considerando-se, porém, a educação (e outros bens) como direito social, translada-se de uma mera ideia de prestação estatal para os pobres (ou, no caso chileno, de seguro que garante acesso ao mercado educacional), para uma ideia de bem público e direito do cidadão. É calcado nessa ideia que, no sexto capítulo, o autor apresenta os três princípios que embasariam o funcionamento do mercado e, em oposição, os três princípios de um sistema baseado na concepção de direitos sociais. Em primeiro lugar, se no mercado cada um atua

4 Tradução livre da autora do trecho que segue: "[...]afirmar que algo es un derecho social no implica sostener que no es escaso, sino que, como aquello que es escaso es parte del contenido de la ciudadania, su distribución debe ser igualitaria entre todos los que tienen derecho".

50 autor considera o governo de "concertación", que governou durante a transição para a democracia, como uma versão humanizada do neoliberalismo. Sobre isso, ver ATRIA, Fernando. Veinte años después, Neoliberalismo com rostro humano. Santiago: Catalonia, 2013. 
baseado no seu próprio interesse, a provisão de um direito social é feita porque o provedor serve ao interesse do cidadão. Em segundo lugar, enquanto no mercado ninguém tem o dever de provisão ou o direito a receber antes da assinatura de um contrato, a própria existência de um direito social do cidadão implica em um dever de provisão. Por último, enquanto no mercado cada um é livre para oferecer e contratar as condições que desejar, no caso de um direito social as condições de oferta não podem ser estabelecidas nem unilateralmente, nem para cada caso específico. Essas condições, pelo contrário, deverão estar especificadas em um protocolo público universal, definido politicamente.

É a partir dessa ideia que Atria delimitará seu conceito-chave de público- que diferencia do que é meramente estatal- e do que chama de "regime do público" (2014, p. 218). Pensando nesses três princípios defenderá que a superação de um sistema de mercado na educação depende de colocar fim ao lucro, à seleção dos estudantes e garantir a gratuidade universal. É com base nisso tudo que traçará seu caminho alternativo para o sistema educacional chileno. Caminho, este, que retomaria uma uma lógica de cidadania e semearia um novo paradigma que, pouco a pouco, superaria o estado civil de conveniência geral, em que a visão do outro é instrumental. Num caminho gradual, a repolitização dos direitos sociais e a retomada da noção de um regime do público são meios e fins de um caminho que tem como direção de movimento uma sociedade mais justa, que, certamente, não estará livre de problemas. Entretanto, sob um novo paradigma que foi e seguirá sendo construído em uma pedagogia lenta, esses problemas e a forma de resolvê-los se torna outra, que baseia-se na compreensão de um bem comum compreendido e definido politicamente. E é com essa noção de regime do público, que reestabelece o papel do estado como esfera distinta do mercado e aponta um horizonte para as políticas públicas em educação, que Atria faz sua reflexão situada e enraizada no contexto chileno transcender fronteiras e ajudar também a aprimorar nosso olhar sobre o contexto brasileiro. 